\title{
The Bird Coming out of the Cage: Edna’s Awakening in The Awakening*
}

\author{
Zhang Yan-hua \\ Weifang Medical University, Weifang City, China
}

\begin{abstract}
The Awakening was Kate Chopin's masterpiece, describing a wealthy businessman's wife-Edna's confusion, awakening, pursuit, and suffocation of self-awareness in the South of America in the late 19th century. With the method of close reading in new criticism, this paper reinterprets Edna's awakening process. Her awakening process is accompanied by the symbolic image of "bird”, representing women's situation in the patriarchal society and carrying Edna's hope for freedom, love, and self-realization. The application of bird's symbolic image reflects Kate Chopin's compassion for women in the patriarchal society, making the novel more appealing with its profound humanitarian connotations.
\end{abstract}

Keywords: the Awakening, Edna, symbolic image of bird, self-awareness

\section{Introduction}

The Awakening was Kate Chopin's masterpiece, describing a wealthy businessman's wife—Edna's confusion, awakening, pursuit, and suffocation of self-awareness in the South of America in the late 19th century. After the novel was published, it received floods of accusation because of the author's neutral attitude to Edna's extramarital affair. It was labeled as “moral poison” and banned, disappearing from the scene for half a century. With the rise of the second wave of feminism in 1970s, Kate Chopin became the object of literary attention again.

The contents of The Awakening are interpreted in different periods, giving rise to different reflections, while the creative art revealed in this novel is internationally acknowledged. In 1899, when the novel was published, C. L. Deyo ever said, "it is sad and mad and bad, but it is all consummate art” (Martin, 2007, p. 12). In 1952, V. W. Brooks admitted that "The Awakening was one novel of the nineties in the South that should have been remembered, one small perfect book that mattered more than the whole life-work of many a prolific writer” (Martin, 2007, p. 12). Kate Chopin applies symbolism, metaphor, and personification to unfold Edna's awakening process and her psychological activities, which is near the dizzy brink of the unreal. In the novel the luxuriant images mixes together, becoming one of the most important characteristics.

\footnotetext{
* Acknowledgements: This paper is part of the author's academic studies project sponsored by Social Science Planning Fund Program, Shangdong Province (13CWJZ18) \& Medical Education Branch of Chinese Medical Association Program (2012-YY-17).

Zhang Yan-hua, master, associate professor, English Department, Weifang Medical University.
} 


\section{Bird's Image in Literature}

"Bird" is one of frequently-used symbolic images in Greek myth, fairy tales, and some classic works of literature. It often plays a role to bring out the crucial point in displaying scenarios, shaping characters and revealing themes. Baker (1999, p. 37) notes that "the way we identify women reflects our conception of them, and that most terms used to identify women place them as non-human or as minors”.

With the exception of the hummingbird, which, like all the birds suggested, is generally thought to be diminutive and pretty, all of the birds are domesticated, usually as pets (which reminds one that "my pet" is an expression of endearment). None of the birds were predators or symbols of intelligence or nobility. (Baker, 1999, p. 38)

In literary works, these images associated with females symbolize women's objectification. Coincidentally, in Chinese culture, there are also some similar metaphors. For example, in the idiom "as a little bird rests upon a man", the "bird" also refers to a gentle, lovely woman, but she also relies on others (esp. a man) for survival because of the lack of independent personality.

In British and American Culture, it has a long history that "birds” are used to signify women's situation in patriarchal society. In 1655, Margaret Cavendish, a famous British poet and philosopher, expressed her opinion in the book Philosophical and Physical Opinions. She symbolized women's inferior position as "birds in a cage” for the first time,

We are kept like birds in cages to hop up and down in our houses, not suffered to fly abroad... we are shut out of all power and authority, by reason we are never employed either in civil or martial affairs, our counsels are despised and laughed at, the best of our actions are trodden down with scorn, by the overweening conceit men have of themselves and through despisement of us. (Walters, 2008, p. 21)

In 1792, Mary Wollstonecraft, one of the British founding feminist philosophers, also applied the same metaphor in her famous book A Vindication of the Rights of Woman, "Taught from their infancy that beauty is a woman's scepter, the mind shapes itself to the body and roaming round its gilt cage, only seeks to adore its prison" (Walters, 2008, p. 33). In the book, she argued that women are not naturally inferior to men, but appeared to be only because they lacked education and were separated from the society. She suggested that both men and women should be treated as rational beings and imagined a social order founded on reason. A century passed, when the book was published in the late 19th century, women's situation was not improved in the South of America.

In the Awakening, the symbolic image of "bird" is endowed some significations, representing women' situation in the patriarchal society at the end of 19th century, carrying Edna's hope for freedom, love, and self realization. With the method of close reading in new criticism, this paper reinterprets Edna's awakening process.

\section{Edna: A Bird in the Cage}

Birds should fly in the sky freely. At the very beginning of the novel, what we read is "a green and yellow parrot, which hung in a cage outside the door, kept repeating over and over" (Chopin, 2007, p. 1). The bird was lonely because it had no freedom and no communication with others, signifying Edna's situation: "a bird in a cage”. 
Edna was once satisfied with her life, her two sons are smart and her husband was a wealthy businessman in New Orleans, capable and credible. There were also housemaids to look after the children and cook meals, so she was unnecessary to carry the heavy burdens of housework as other women did. Even though she lived a relatively comfortable life, Edna had no opportunities to choose her own life like every female in the late of the 19th century, "The home is the centre and circumference, the start and the finish, of most of our lives". A woman was defined as “someone’s daughter, someone’s wife, someone’s mother, someone’s mistress” (Martin, 2007, p. 14). What Edna could do is to look after the children and to study the recipe, telling the servants what to cook to please her husband. On Tuesday, as a hostess, she had to treat visitors at home as usual. For six years, she repeated the rituals, feeling "there were days when she was unhappy, she did not know why-when it did not seem worthwhile to be glad or sorry, to be alive or dead; when life appeared to her like a grotesque pandemonium and humanity like worms struggling blindly toward inevitable annihilation” (Chopin, 2007, p. 85). Although she could accompany her husband to concerts or theoretical plays at weekends, she was unpleasant.

Edna's father was arbitrary and tyrannical, her mother died when Edna was young. Even as a child she had lived her own small life all within herself. "At a very early period she had lived her own small life all within herself. At a very early period she had apprehended instinctively the dual life —-that outward existence which conforms, the inward life which questions” (Chopin, 2007, p. 20). Mr. Pontellier was 12 years older than her, being tied up in business, they had no common interests or hobbies. The lack of spiritual communication impaired their emotion, the sacred marriage was regarded as the shackles in Edna' eyes.

She considered herself as those expensive furniture and artifacts of equal status without physical and mental freedom. Even, "The children appeared before her like antagonists who had overcome her; who had overpowered and sought to drag her into the soul's slavery for the rest of her days” (Chopin, 2007, p. 166).

Edna was fond of arts, liking drawing or playing piano. She was unwilling to be her husband and children's vassal, unwilling to exist just as an object. She had a faint feeling, "an indescribable oppression, which seemed to generate in some unfamiliar part of her awareness, like a mist passing across her soul's summer day" (Chopin, 2007, p. 12). Due to the lack of spiritual value, Edna felt like “a bird in a cage”, she longed for physical and psychological freedom and self-realization.

\section{Sprouting of Edna's Self-awareness}

Edna's self-awareness had greatly influenced by her two intimate friends, Adele and Reisz. Adele was a representative of traditional value in Creole culture. She was a mother-woman, "who idolized their children, worshiped their husbands, and esteemed it a holy privilege to efface themselves as individuals and grow wings as ministering angels” (Chopin, 2007, p. 11). She was frank and straightforward. Under her influence, Edna did not repress her emotions and began to express her own voice. "It muddled her like wine, or like a first breath of freedom” (Chopin, 2007, p. 26).

Reisz was a rebellious musician, who despised the traditional custom, which confined women's development. She was neglectful of her appearance with an independent spirit, not young but still remained single. Reisz was the only one who can understand Edna's pursuit. They both loved art, advocating physical and psychological independence. Reisz's music touched and inspired her. Edna had a strong feeling to think of 
women as the independent individuals. Reisz told her to have enough courage, because "the bird that would soar above the level plain of tradition and prejudice must have strong wings. It is a sad spectacle to see the weaklings bruised, exhausted, fluttering back to earth” (Chopin, 2007, p. 120).

Adele's wings were designed for an angel, a woman as an understanding wife and a devoted mother; Reisz flew above the traditional custom, unable to be understood by common people. Kate Chopin succeeded using the symbolic imagery "birds" to portray the two different females. Edna was reluctant to completely take family as the center of her life as Adele; nor did she devote herself to art as Reisz to endure loneliness. When listening to "Solitude" Reisz played, she would have an image of a lonely man in her mind, standing on the beach on the reef: "He was naked. His attitude was one of hopeless resignation as he looked toward a distant bird winging its flight away from him” (Chopin, 2007, p. 37). Edna was eager to have freedom as a man, her lonely mood completely unmasked.

Because of the traditional custom, Edna was full of confusion, hesitation, "sometimes I feel this summer as if I were walking through the green meadow again; idly, aimlessly, unthinking and unguided” (Chopin, 2007, p. 24). She was expecting to realize her position in the universe as a human being, persisting in her exploration. After she learned to swim, she felt "she grew daring and reckless, overestimating her strength". She wanted to swim "far out, where no woman had swum before" (Chopin, 2007, p. 40).

\section{Edna's Awakening}

During the summer vacation at Grand Isle, Edna met Robert, a young man who disrupts her quiet life with his romance and passion. They had so many things to share together, which made a sharp contrast compared with her husband. She thought as if "she were being borne away from some anchorage which had held her fast, whose chains had been loosening - had snapped the night before when the mystic spirit was abroad, leaving her free to drift whithersoever she chose to set her sails" (Chopin, 2007, p. 50). Edna's self-awareness was awakening, she could realize that "she herself-her present self-was in some way different from the other self". She began to see the world with different point, "making the acquaintance of new conditions in herself that colored and changed her environment" (Chopin, 2007, p. 59).

Robert was forced to leave for Mexico to escape his love to Edna, because of the pressure of tradition and custom. In Edna's eyes, "Robert's going had some way taken the brightness, the color, the meaning out of everything” (Chopin, 2007, p. 67) .

After Edna quarreled with her husband, she tore her handkerchief into ribbons, taking off her wedding ring, flung it upon the carpet and broke a glass vase. She wanted to release her discontent and anger. When the servant entered, she picked up the ring and wore it again, as if nothing had happened. Her contradictory mind is revealed here again,

At the turn of the century, when the Awakening was published, marriage in New Orleans was based on the Napoleonic Code, which defined a wife and everything she possessed, including her clothes, as her husband's property. Divorce was in infrequent and scandalous event, particularly in Louisiana, which was a Catholic state... and until 1888 the custody of children was automatically given to the husband. (Martin, 2007, p. 17)

But, "her small boot heel did not make an indenture, not a mark upon the little glittering circlet" (Chopin, 2007, p. 77). It was difficult for Edna to get rid of social imprisonment for women, it was difficult for to get rid 
of the marriage cage, her helplessness is revealed here.

When Edna's husband was on a business travel with her children being taken to grandma's home, she felt the freedom she longed for, "now that her time was completely her own to do with as she liked" (Chopin, 2007, p. 106). She realized she had neglected her reading, planning to start anew upon a course of improving studies and read Emerson's books, which make her more considerate of female's existence as an individual. Loyalty, responsibility, and ethics did not confine her any longer; she had an affair with Arobin, a dissolute young man. Her latent sensuality, which unfolded under his delicate sense of her nature's requirements, was "like a torpid, torrid, sensitive blossom” (Chopin, 2007, p. 151). Adele’s persuasion did not work, she began to live in new experiences: She had not been associating with anybody else; She had abandoned her Tuesdays' duties at home and ignored all her acquaintances; She no longer tried to restrain herself in the church, or to restrain herself around the home; She refused to attend her sister's wedding without giving any excuses. She was learning to perceive the world with her own eyes and with her own heart: painting, swimming, horse racing, trying to be financially independent.

Edna left the luxurious mansion and moved into a small "dove nest", with the things she earned, not given by her husband. She began to work and live a simple life. At this time, she felt "there was with her a feeling of having descended in the social scale, with a corresponding sense of having risen in the spiritual” (Chopin, 2007, p. 136).

\section{The Ending of Edna's Awakening}

Like a bird out of its cage, spreading its wings, Edna tried to observe the world with her own eyes, understanding the true meaning of life, painting, swimming, horse racing. She followed her own inclinations with adventitious ideas about.

When Edna knew that Robert will return from Mexico, she could not resist her excitement and expectation,

She was already glad and happy to be alive at the mere thought of his return. The murky, lowering sky, which had depressed her a few hours before, seemed bracing and invigorating as she splashed through the streets on her way home. (Chopin, 2007, p. 118)

When they met again, Robert's concerns to the reality broke Edna's vision,

You have been a very, very foolish boy, wasting your time dreaming of impossible things when you speak of Mr. Pontellier setting me free! I am no longer one of Mr. Pontellier's possessions to dispose of or not. I give myself where I choose. (Chopin, 2007, p. 156)

Adele's fourth parturient made Edna feel the reality imposed to women; Adele's advice to "think of children”, made her feel the helplessness of life. Under the pressure, Robert once again escaped, leaving a note "I love you. Goodbye. Because I love you". Edna felt so despaired that she could not imagine the future without Robert, neither did she want to go back to the past without love. Her association with Arobin only brought a shot moment of flesh joy, and left more spiritual emptiness.

However, any behavior that contradicted the roles of a wife, a mother, and a daughter was deemed to discard because it didn't conform to the gender roles of women, these actions clearly violated the social 
customs, posing a threat to her husband's social status and dignity.

Edna realized "By all the codes which I am acquainted with, I am a devilishly wicked specimen of the sex" (Chopin, 2007, p. 119). But she was unwilling to accept this, "There are periods of despondency and suffering which take possession of me. But I don't want anything but my own way” (Chopin, 2007, p. 162). However, it was not available for females to do what they wanted to do at that time. Education that most girls were given merely conforms to the pattern. Therefore, "any symptom of independent thought is quickly repressed... The majority of girls are subdued into mere automatons" (Walters, 2008, p. 42). The formation of the word "normal" tells people clearly, people who abide by "norm" are "normal"; Otherwise, they will be regarded as "abnormal”. Edna's self-awareness, sexual awareness, and social awareness were destined to be ignored or inhibited in the patriarchal society; females could not have the wings because of the lack of the social environment. Even though some of them did have the wings, they could not fly in the sky to after they go out of the cages. At last, Edna was like "A bird with a broken wing was beating the air above, reeling, fluttering, circling disabled down, down to the water” (Chopin, 2007, p. 167).

\section{Conclusion}

In the Awakening, Kate Chopin Author Chopin mixes a variety of symbolic images, the sea, birds, islands, swimming, the sun, the mist, flowers, rings and ropes, which are contributive to the colorful and artistic text. As the key image of the novel, "bird" appears repeatedly in the text, incisively reflects Edna's awakening from confusion, pursuit to suffocate process. From Edna's original position- “a bird in a cage”, to her friend, Reisz's advice "the bird that would soar above the level plain of tradition and prejudice must have strong wings", to the end of the novel that only "a bird with a broken wing was beating the air above, reeling, fluttering, circling disabled down, down to the water". The consistent symbolic imagery "bird" deepens the theme of the novel and reflects Kate Chopin's compassion for females' situation in patriarchal society, making the novel more appealing and have profound humanitarian connotations.

In the male-oriented world in 19th Century, Edna had the courage to pursue self-realization and love, "I would give up the unessential; I would give my money, I would give my life for my children; but I wouldn't give myself" (Chopin, 2007, p. 69). She thought "perhaps it is better to wake up after all, even to suffer, rather than to remain a dupe to illusions all one's life” (Chopin, 2007, p. 162). She dared to challenge the fetters of the traditional society of women. What revealed in her remarks was her determination and persistence, making readers moved even shocked. Edna's awakening undoubtedly had its profound meaning. At the same time, when she struggled to break the bondage of the society, completely and entirely forgetting her responsibilities in family or society, she chose an extreme alternative. Edna realized "her position in the universe as a human being” (Chopin, 2007, p. 19), but she didn't realize her relations as an individual to the world within and about her". As an individual in the society, she forgot her social attributes, ignoring the existence of all her sons or her sisters, making individual value completely opposite to the social responsibility. When she struggled to go out of the cage, she could not balance her responsibility as a mother and an individual due to limitation of the time. Finally, she, just like the wounded bird with broken wings, fell into the sea. 


\section{References}

Baker, R. (1999). “Pricks” and “Chicks”: A plea for "Persons”. In J. A. Kourany, J. P. Sterba, \& R. Tong (Eds.), Feminist philosophies: Problems, theories, and applications (pp. 34-35) (2nd ed.). Upper Saddle River: Prentice Hall.

Chopin, K. (2007). The awakening. Shanghai: Shanghai Foreign Language Education Press.

Martin, W. (2007). New essays on the awakening. Beijing: Peking University Press.

Walters, M. (2008). Feminism: A very short introduction. Beijing: Foreign Language Teaching and Research Press. 